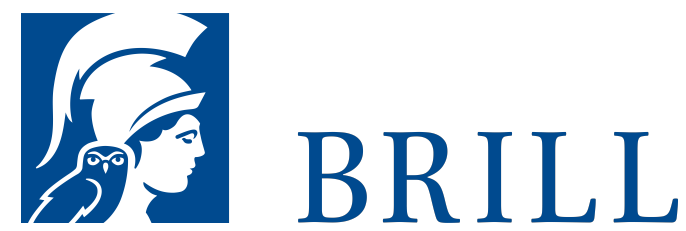

\title{
Tierethik - Der Comic zur Debatte
}

\author{
Authors:Julia Kockel and Oliver Hahn
}

Unser Verhältnis zu Tieren ist vor allem eins - ambivalent. Wir betrauern das Schicksal rumänischer Straßenhunde und spenden für das Überleben der letzten Tiger. Wir bringen unseren Kindern bei, keine Tiere zu quälen - nicht einmal Insekten. Gleichzeitig entsorgen wir in Deutschland im Jahr rund 5 o Millionen männliche „Abfallküken“ und schlachten in etwa genauso viele Schweine. Wir bauen unseren Lebensstandard auf dem Leben und Sterben diverser Tierarten auf. Aber können wir dieses Verhalten ethisch rechtfertigen? Welche Eigenschaft spricht einem Lebewesen einen moralischen Wert zu? Hat ein Menschenaffe ein Recht auf Leben, ein Säugling aber nicht? Darf ein Tier ein menschliches Eigentum sein? Wo ziehen wir die Grenze? - Mit diesen Fragen beschäftigt sich die Tierethik. Der Comic zeichnet die Debatte um das Tier nach, die in der Antike ihren Anfang nahm und bis heute andauert. Er stellt die prominenten tierethischen Positionen vor und befasst sich mit der Frage nach den soziologischen und politischen Bedingungen für eine angewandte Ethik zwischen Mensch und Tier. Die Geschichte der Tierethik ist zugleich ein philosophischer Streifzug durch die Landschaft der allgemeinen ethischen Theorien (vom Utilitarismus, über die Theorie der Rechte bis zur feministischen Fürsorge-Ethik) - durch die uns der Comic ortskundig führt und uns hilft ihre Komplexität durch ein... See More

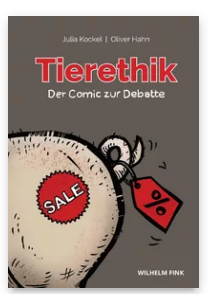

Pages: 156 Seiten Language: German

Subjects: General, Philosophy

Publisher: Brill | Fink

E-Book (PDF)

Released online: 16 Sep 2019 ISBN: $978-3-$ 8467-6289-9 List price Paperback Publication date: 29 Sep 2017

ISBN: $97^{8-3-}$ 7705-6289-3 List price 
Julia Kockel arbeitet derzeit als Übersetzerin und freie Lektorin. Der vorliegende Comic beruht auf der langjährigen Auseinandersetzung mit dem Thema Tierphilosophie und Tierethik.

Oliver Hahn arbeitet als freiberuflicher Grafiker und Illustrator in Aachen. Neben der Kunst gilt sein Interesse der utopischen bzw. dystopischen Literatur, humanistischen

Reformbewegungen und dem politischen Weltgeschehen.

For more information see brill.com

\author{
Order information: Order online at brill.com \\ +44330 3330049 | customerservices@brill.com \\ Submission information: brill.com/authors
}

Titles published by Brill | Fink, Brill | mentis or Brill | Schöningh: +49(o)71 5413279216 | brill@brocom.de 